\title{
JURNAL PENGARUH KUALITAS PRODUK DAN KUALITAS LAYANAN TERHADAP KEPUASAN KONSUMEN KING CAKE
}

\author{
Monica Maria (monica_october91@hotmail.com) \\ Mohamad Yusak Anshori (yusak.anshori@ciputra.ac.id)
}

Fakultas Entrepreneurial Business, Universitas Ciputra Surabaya

\begin{abstract}
The main purpose of this research is to identify the influence of product quality $\left(X_{1}\right)$ and service quality $\left(X_{2}\right)$ towards King Cake's customer satisfaction $(Y)$. The population of this research is King Cake's customers. The sample size is 63 respondents. Respondents are selected using non-probability sampling, which is Purposive Sampling. This research uses multiple linear regression analysis. The validity and reliability testing to each indicator is taken before performing the multiple linear regression analysis. The research shows that product quality $\left(X_{1}\right)$ and service quality $\left(X_{2}\right)$ significantly influences King Cake's customer satisfaction $(Y)$. The finding shows that service quality $\left(X_{2}\right)$ gives more significant value towards customer satisfaction $(Y)$ than product quality $\left(X_{1}\right)$ does.
\end{abstract}

Keywords: product quality, service quality, customer satisfaction, King Cake

\section{PENDAHULUAN}

Industri makanan kini bukan hanya menawarkan makanan pokok (main course) saja, tetapi juga makanan ringan seperti kue kering, roti, serta cake (Anwar 2010:2). Persaingan di industri makanan dan minuman pun semakin ketat. Perusahaan harus memiliki competitive advantage agar dapat memenangkan persaingan, salah satu caranya adalah dengan memenuhi keinginan konsumen (consumer oriented). Konsumen akan memilih produk dan jasa yang memberikan nilai terbesar bagi mereka. Jadi, cara untuk mempertahankan pasar adalah dengan membuat konsumen puas, termasuk dengan memberikan mutu produk dan kualitas layanan yang terbaik (Anshori 2007:18; Kotler 2010:20-23).

Kualitas produk merupakan salah satu faktor yang mempengaruhi kepuasan konsumen. Kualitas produk ditentukan oleh sekumpulan kegunaan dan fungsinya, termasuk kinerja/ performance, daya tahan, kesesuaian dengan spesifikasi, estetika produk, dan juga perceived quality/ kesan produk (Mullins dan Boyd dalam Kotler 2009:362). Produk dengan kualitas yang bagus dan terpercaya akan senantiasa tertanam dibenak konsumen, karena konsumen bersedia membayar sejumlah uang untuk membeli produk tersebut (Majalah Service Excellence Edisi 02/II, 2012:24-26).

Meskipun mempunyai kualitas produk yang baik, hal tersebut belum tentu membuat konsumen puas. Kepuasan konsumen juga tergantung pada kualitas layanan yang ditawarkan oleh perusahaan. Kualitas layanan adalah setiap tindakan/ kegiatan yang ditawarkan oleh satu pihak kepada pihak lain, biasanya tidak berwujud (Kotler 2009:386).

Masalah kepuasan konsumen menjadi semakin kompleks karena perusahaan perlu memperhatikan aspek-aspek lain yang ada pada kualitas produk dan kualitas layanan (Wibisono 2011:50-51). Pada dasarnya tujuan dari suatu bisnis adalah untuk memperoleh laba yang besar dan juga menciptakan konsumen yang puas. Terciptanya kepuasan konsumen dapat memberikan beberapa manfaat, diantaranya hubungan antar 


\section{Monica Maria \\ Mohamad Yusak Anshori}

perusahaan dan konsumen menjadi harmonis, terciptanya loyalitas konsumen, dan juga membentuk suatu rekomendasi word of mouth (Tjiptono 2008:24).

King Cake merupakan salah satu usaha UKM (Usaha Kecil Menengah) yang bergerak dalam bidang industri makanan, khususnya cake dan pudding cake. King Cake baru berdiri pada bulan Agustus 2011. King Cake selalu meminta feedback dari konsumen sehingga dapat mengetahui kualitas kinerja King Cake. Tingginya tingkat kritik dan saran terhadap kualitas produk maupun kualitas layanan menjadikan King Cake perlu meninjau ulang kualitas produk dan kualitas layanan yang telah dilakukan apakah berpengaruh terhadap kepuasan konsumen King Cake.

\section{LANDASAN TEORI DAN PENGEMBANGAN HIPOTESIS}

\section{Hubungan antara kualitas produk dan kualitas layanan terhadap kepuasan konsumen}

Kotler (dalam Sunyoto 2012:69) mengatakan bahwa definisi produk adalah segala sesuatu yang ditawarkan pada sebuah pasar untuk diperhatikan, digunakan, dan dikonsumsi sehingga dapat memuaskan keinginan/ kebutuhan konsumen. Produk juga dapat didefinisikan sebagai atribut fisik, psikologi, dan simbolis yang bisa menghasilkan kepuasan maupun manfaat bagi konsumen (Keegan 2007:76). Sekelompok atribut penting dalam suatu produk akan mempengaruhi sikap puas/ ketidakpuasan konsumen terhadap produk atau jasa tertentu. Dengan adanya kualitas yang bagus dan terpercaya, produk akan senantiasa tertanam dibenak konsumen karena konsumen bersedia membayar sejumlah vang untuk membeli produk yang berkualitas (Kotler dan Armstrong dalam Saputra 2010:27). Peleg, Cronin dan Preis (dalam Sun 2008:482-484) mengemukakan bahwa atribut kualitas produk makanan dapat dilihat dari segi:

a. Tampilan fisik

Produk dilihat dari warna, hiasan, dan juga bentuknya. Warna yang menarik dan hiasan serta bentuk yang bagus mempunyai nilai jual yang tinggi. Contoh: perpaduan warna yang terang mempunyai nilai jual lebih tinggi dibandingkan perpaduan warna gelap.

b. Kesesuaian atas spesifikasi

Kualitas dari produk yang dijual harus sesuai dengan yang dijanjikan. Produk yang ditawarkan mampu memberikan ukuran serta diameter yang sesuai dengan yang dijanjikan.

c. Variasi yang banyak

Variasi makanan/ cake yang banyak akan menarik untuk dilihat sehingga aspek ini menjadi alasan mengapa konsumen membeli produk tersebut.

Sedangkan menurut Zeithaml, Parasuraman, dan juga Berry (dalam Sunyoto 2012:187), kualitas layanan merupakan persepsi pelanggan terhadap keunggulan suatu layanan. Kualitas layanan dapat disimpulkan sebagai suatu manfaat yang dapat dirasakan oleh konsumen dan sifatnya intangible (Stanton dalam Sunyoto 2012:186). Kualitas layanan sendiri ditentukan oleh lima dimensi kualitas layanan yaitu:

a. Dimensi reliability/ kehandalan yang meliputi kemampuan perusahaan untuk memberikan pelayanan terbaik kepada konsumennya.

b. Dimensi responsiveness/ tanggapan yang meliputi keinginan perusahaan untuk memberikan pelayanan yang cepat dan tanggap.

c. Dimensi assurance/ kepastian yang meliputi kemampuan perusahaan untuk membangkitkan rasa kepercayaan pelanggan mengenai produknya.

d. Dimensi emphaty/ empati yang meliputi rasa kepedulian dan perhatian secara pribadi yang diberikan pada pelanggan.

e. Dimensi tangibles/ penampilan fisik yang meliputi penampilan/ bukti fisik. 
Pada prinsipnya, kualitas layanan berfokus pada upaya pemenuhan kebutuhan dan keinginan pelanggan, serta ketepatan untuk mengimbangi harapan konsumen (Kotler dalam Sunyoto 2012:193). Menurut penelitian yang dilakukan oleh Abdullah, et al., (2012) dan Anshori (2007), pada dasarnya, seluruh kegiatan yang dilakukan oleh sebuah perusahaan bertujuan untuk memberikan nilai lebih pada pelanggan sehingga akhirnya pelanggan merasa puas. Kepuasan dapat diartikan sebagai perbandingan antara persepsi konsumen terhadap hasil pengalaman yang dirasakan terhadap produk yang bersangkutan. Hal ini berupa perasaan pelanggan setelah membandingkan antara harapan dengan kinerja aktual perusahaan. Apabila kinerja perusahaan jauh lebih rendah ketimbang harapan, konsumen merasa tidak puas, jika kinerja melebihi harapan, maka0 konsumen merasa amat puas. Konsumen yang merasa amat puas dan konsumen yang merasa puas akan loyal dan mereka akan memberikan informasi kepada orang lain mengenai pengalaman baik dengan kinerja yang dirasakan. Kuncinya adalah memenuhi harapan konsumen (Kotler 2010:201-202). Perusahaan tidak hanya sekedar menciptakan produk, tetapi mereka juga ingin memelihara konsumen. Kepuasan konsumen merupakan hal yang penting dalam suatu perusahaan karena dengan banyaknya konsumen yang puas dapat membawa keuntungan bagi perusahaan (Anshori 2007:18).

\section{Model Analisis dan Hipotesis}

$\mathrm{H}_{1}$ : Kualitas produk dan kualitas layanan secara simultan berpengaruh terhadap kepuasan konsumen King Cake.

$\mathrm{H}_{2}$ : Kualitas produk secara parsial berpengaruh terhadap kepuasan konsumen King Cake.

$\mathrm{H}_{3}$ : Kualitas layanan secara parsial berpengaruh terhadap kepuasan konsumen King Cake.

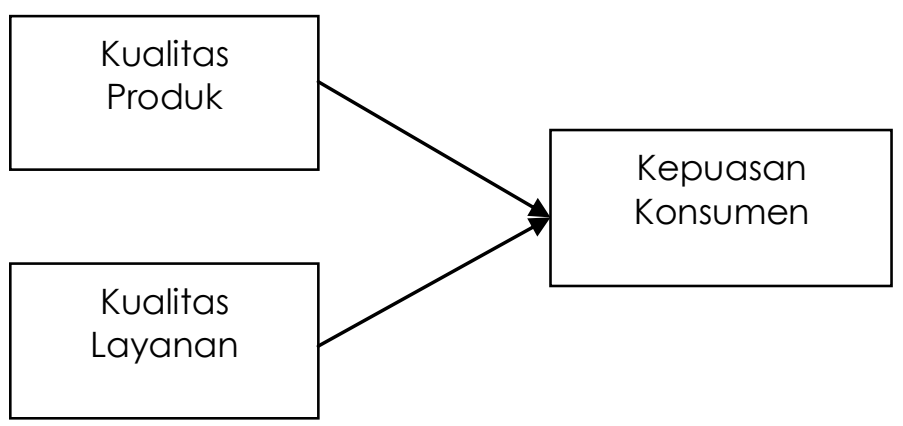

\section{METODE PENELITIAN}

\section{Rancangan Penelitian}

Secara umum terdapat empat tipe penelitian sosial yaitu penelitian historis, penelitian korelasional, penelitian deskriptif, dan penelitian kausal komparatif. Penulisan dilakukan dengan menggunakan metode deskriptif dan inferensial, yaitu penelitian yang mengumpulkan data secara sistematis untuk menjawab hipotesis yang berkaitan dengan subjek penelitian. Penelitian ini juga digunakan sebagai dasar dalam pengambilan keputusan bisnis dan juga untuk mengenali distribusi serta perilaku data yang dimiliki (Lind, et al., 2007:6; Kuncoro 2009:12). Penelitian ini menggunakan pendekatan kuantitatif yaitu sebuah pendekatan penulisan yang analisis datanya dilakukan dengan menggunakan metode statistik. Paradigma kuantitatif menekankan pada pengujian teori melalui pengukuran variabel penulisan dengan numerik/ angka dan pengukuran tersebut sifatnya terkontrol serta menonjol (Lind, et al. 2007:9; Sugiyono 2008:3-4).

\section{Populasi}




\section{Monica Maria \\ Mohamad Yusak Anshori}

Populasi adalah suatu himpunan individu/ objek tertentu yang banyaknya diperoleh dari semua individu/ objek tertentu (Lind, et al. 2007:7; Sugiyono 2008:6). Populasi dalam penelitian ini yaitu seluruh konsumen yang pernah membeli produk King Cake. Berdasarkan data dari bulan Agustus 2011 hingga Juli 2012, populasi konsumen King Cake berjumlah 234 orang, sedangkan konsumen yang melakukan repeat order berjumlah 64 orang.

\section{Sampel dan Teknik Pengambilan Sampel}

Sampel adalah bagian dari suatu populasi yang mewakili karakteristik populasi untuk diteliti (Lind, et al. 2007:7; Sugiyono 2008:6). Pengambilan sampel dilakukan dengan menggunakan metode non-probabilitas yaitu menggunakan teknik Purposive Sampling. Sampel diambil berdasarkan kriteria tertentu (Kuncoro 2009:139). Dalam hal ini, kriteria yang digunakan oleh penulis adalah konsumen yang setidaknya pernah membeli produk King Cake lebih dari dua kali di Surabaya.

Cara untuk menghitung sampel didasarkan pada rumus Slovin sebagai berikut:

$$
\begin{aligned}
& n=\frac{N}{1+N e^{2}} \\
& n=\frac{170}{1+170(0.10)^{2}}=62,96 \approx 63
\end{aligned}
$$

(Umar, 2008:78)

Keterangan:

$\mathrm{n}=$ ukuran sampel

$\mathrm{N}=$ ukuran populasi

$\mathrm{e}=$ persentase tingkat kesalahan pengambilan sampel sebesar $10 \%$

Berdasarkan rumus Slovin, ditemukan bahwa jumlah sampel yang digunakan dalam penelitian sebanyak 63 responden.

\section{Instrumen Penelitian}

Alat utama dalam penelitian ini berupa kuesioner yang diberikan kepada konsumen King Cake di Surabaya yang terpilih menjadi sampel penelitian. Dalam kuesioner terdapat sejumlah pertanyaan yang harus dijawab oleh responden sesuai dengan hal-hal yang diketahuinya. Peneliti menggunakan analisa regresi linier berganda. Didalamnya akan diuji validitas dan reliabilitas. Uji validitas dan reliabilitas dilakukan untuk mengetahui apakah alat ukur yang digunakan sudah tepat dan dapat dipercaya kebenarannya. Selanjutnya, setelah asumsi-asumsi terpenuhi, maka dilakukan pengujian kelayakan model.

\section{HASIL PENELITIAN DAN PEMBAHASAN}

\section{Responden Penelitian}

Mayoritas responden adalah wanita dengan usia di atas 35 tahun (61,9\%), sedangkan responden pria menunjukkan prosentase $38,1 \%$. Mayoritas responden adalah ibu rumah tangga yaitu sebanyak 37 orang (58,7\%). Kondisi ini sesuai dengan argumen Schiffman dan Kanuk (2008:45) yang mengatakan bahwa wanita biasanya lebih mengarah ke produkproduk seperti kecantikan, perawatan, makanan ringan, rambut, dan sebagainya. Sedangkan konsumen pria lebih mengutamakan kebutuhan-kebutuhan kerja dan olahraga. Adapun kebanyakan responden King Cake didominasi oleh ibu rumah tangga $(42,9 \%)$ karena biasanya yang mengurus hal-hal berkaitan dengan makanan adalah ibu rumah tangga. 


\section{Uji Validitas dan Reliabilitas Instrumen}

Sebuah kuesioner dinyatakan valid apabila alat ukur tersebut mampu mengukur data secara aktual, serta mampu mengungkapkan data suatu fenomena yang diteliti dengan tepat. Uji validitas dilakukan terhadap setiap butir pernyataan dari variabel-variabel penelitian dengan menggunakan uji korelasi Pearson. Hasil dari perhitungan tersebut akan dibandingkan dengan tingkat signifikansi yang digunakan. Dalam hal ini, peneliti menggunakan tingkat signifikansi $10 \% / a=0,10$. Bila signifikansi lebih rendah daripada taraf signifikansi, maka pernyataan tersebut dianggap valid (Sarwono dan Martadiredja 2008:86; Sunyoto 2009:67-72). Setelah melakukan uji validitas, maka selanjutnya dilakukan uji reliabilitas terhadap ketiga variabel. Sebuah alat ukur dinyatakan reliabel jika nilai Cronbach Alpha lebih besar dari 0,6 dan nilai Cronbach Alpha if item deleted lebih kecil dari nilai Cronbach Alpha (Sunyoto 2009:67-72). Variabel kualitas produk, kualitas layanan, dan kepuasan konsumen telah diuji dan diperoleh hasil bahwa setiap butir pernyataan pada ketiga variabel tersebut valid serta reliabel.

\section{Hasil Analisis Regresi Linier Berganda}

Regresi linier berganda adalah sebuah teknik yang digunakan untuk mengembangkan suatu persamaan dan bertujuan untuk mengukur pengaruh dari variabel bebas terhadap variabel terikat (Lind, et al. 2008:120). Penelitian ini bertujuan untuk mengetahui pengaruh kualitas produk $\left(X_{1}\right)$ dan kualitas layanan $\left(X_{2}\right)$ terhadap kepuasan konsumen $(Y)$, baik secara simultan dan secara parsial/ individual.

\section{Uji Statistik F (Uji Simultan)}

Fungsi dari uji $\mathrm{F}$ adalah untuk mengetahui apakah variabel kualitas produk $\left(\mathrm{X}_{1}\right)$ dan kualitas layanan $\left(\mathrm{X}_{2}\right)$ berpengaruh secara bersama-sama terhadap variabel terikat yaitu kepuasan konsumen (Y). Uji hipotesis dilakukan melalui langkah-langkah sebagai berikut:

1) Perumusan hipotesis

$\mathrm{H}_{0}: \beta i=0$

$$
i=1,2
$$

Artinya variabel kualitas produk $\left(X_{1}\right)$ dan kualitas layanan $\left(X_{2}\right)$ secara simultan tidak berpengaruh terhadap variabel kepuasan konsumen $(\mathrm{Y})$. $\mathrm{H}_{1}$ : minimal ada satu $\beta i \neq 0 \quad i=1,2$

Artinya variabel kualitas produk $\left(X_{1}\right)$ dan kualitas layanan $\left(X_{2}\right)$ secara simultan berpengaruh terhadap variabel kepuasan konsumen $(\mathrm{Y})$.

2) Tingkat signifikansi menggunakan $a=0,10$

Bila nilai signifikansi $>0,10$, maka $\mathrm{H}_{0}$ diterima.

Bila nilai signifikansi $<0,10$, maka $\mathrm{H}_{0}$ ditolak.

Tabel 1

Uji $F$

ANOVAb

\begin{tabular}{|c|c|c|c|c|c|}
\hline Model & $\begin{array}{l}\text { Sum of } \\
\text { Squares }\end{array}$ & Df & Mean Square & $\mathrm{F}$ & Sig. \\
\hline Regression & 13,877 & 2 & 6.939 & 63,205 &, $000^{a}$ \\
\hline Residual & 6,587 & 60 & 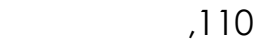 & & \\
\hline Total & 20,464 & 62 & & & \\
\hline
\end{tabular}




\begin{tabular}{|l|r|r|r|r|r|}
\hline Model & \multicolumn{1}{|c|}{ Sum of } & Sf & Mean Square & \multicolumn{1}{|c|}{ F } & \multicolumn{2}{|c|}{ Sig. } \\
\hline Regression & 13,877 & 2 & 6.939 & 63,205 & \\
Residual & 6,587 & 60 &, 110 & & \\
Total & 20,464 & 62 & & & \\
\hline
\end{tabular}

a. Predictors: (Constant), Kualitas_Layanan, Kualitas_Produk

b. Dependent Variable: Kepuasan_Konsumen

Sumber: SPSS

Tabel 1 menunjukkan bahwa nilai signifikansi sebesar $0,000(<0,10)$ sehingga $\mathrm{HO}$ ditolak dan $\mathrm{H} 1$ diterima. Dengan demikian dapat ditarik kesimpulan bahwa secara simultan, variabel kualitas produk $\left(X_{1}\right)$ dan kualitas layanan $\left(X_{2}\right)$ memberikan pengaruh yang signifikan terhadap variabel kepuasan konsumen (Y) (Kuncoro 2009:239).

\section{Uji Statistik † (Uji Individual/ Parsial)}

Uji † digunakan untuk mengetahui apakah variabel kualitas produk $\left(X_{1}\right)$ dan kualitas layanan $\left(\mathrm{X}_{2}\right)$ berpengaruh terhadap variabel kepuasan konsumen $(\mathrm{Y})$ secara individual/ parsial. Apabila nilai signifikansi lebih kecil daripada taraf signifikansi $(0,10)$, maka terdapat pengaruh signifikan secara parsial antara variabel bebas terhadap variabel terikat.

Tabel 2

Uji †

Coefficientsa

\begin{tabular}{|c|c|c|c|c|c|c|c|c|}
\hline \multirow[b]{2}{*}{ Model } & \multicolumn{2}{|c|}{$\begin{array}{c}\text { Unstandardized } \\
\text { Coefficients }\end{array}$} & \multirow{2}{*}{$\begin{array}{c}\text { Standardized } \\
\text { Coefficients } \\
\text { Beta }\end{array}$} & \multirow[b]{2}{*}{ t } & \multirow[b]{2}{*}{ Sig. } & \multicolumn{3}{|c|}{ Correlations } \\
\hline & B & Std. Error & & & & $\begin{array}{l}\text { Zero- } \\
\text { order }\end{array}$ & Partial & Part \\
\hline (Constant) & ,408 &, 355 & & 1,148 & ,255 & & & \\
\hline Kualitas_Produk & 219 & ,121 & 199 & 1,809 & 075 & 695 & 227 & 133 \\
\hline Kualitas_Layanan & 680 & 113 & ,664 & 6,036 & ,000 & 813 &, 615 & ,442 \\
\hline
\end{tabular}

a. Dependent Variable: Kepuasan_Konsumen

Sumber: SPSS

Berdasarkan uji † pada Tabel 2, dapat ditarik kesimpulan sebagai berikut:

1) Kualitas Produk ( $\left.X_{1}\right)$

Nilai signifikansi variabel kualitas produk $\left(X_{1}\right)$ adalah $0,075(<0,10)$, sehingga $\mathrm{H}_{0}$ ditolak dan $\mathrm{H}_{1}$ diterima, maka dapat disimpulkan bahwa variabel kualitas produk $\left(\mathrm{X}_{1}\right)$ secara parsial berpengaruh terhadap kepuasan konsumen (Y) (Kuncoro 2009:238). Nilai korelasi parsial kualitas produk $\left(X_{1}\right)$ sebesar 0,227 menunjukkan bahwa secara parsial, variabel kualitas produk $\left(X_{1}\right)$ memberikan pengaruh yang positif dan searah terhadap variabel kepuasan konsumen (Y).

2) Kualitas Layanan $\left(X_{2}\right)$

Nilai signifikansi variabel kualitas layanan $\left(X_{2}\right)$ adalah $0,000(<0,10)$, sehingga $\mathrm{H}_{0}$ ditolak dan $\mathrm{H}_{1}$ diterima, maka dapat disimpulkan bahwa variabel kualitas layanan $\left(\mathrm{X}_{2}\right)$ secara parsial berpengaruh terhadap kepuasan konsumen (Y). (Kuncoro 2009:238).

Nilai korelasi parsial variabel kualitas layanan $\left(\mathrm{X}_{2}\right)$ yaitu sebesar 0,615 menunjukkan bahwa secara parsial, variabel kualitas layanan $\left(X_{2}\right)$ memberikan pengaruh yang positif dan searah terhadap variabel kepuasan konsumen (Y). Hal ini berarti variabel kualitas layanan $\left(\mathrm{X}_{2}\right)$ mempunyai pengaruh yang lebih besar terhadap kepuasan 
konsumen ( $Y$ ) dibandingkan variabel kualitas produk ( $\mathrm{X}_{1}$ ) (Sugiyono 2008:184; Lind 2008:60).

\section{Pembahasan}

\section{Pengaruh Kualitas Produk Terhadap Kepuasan Konsumen}

Kualitas produk berpengaruh positif terhadap kepuasan konsumen. Hal ini berarti semakin baik kualitas produk yang diberikan oleh King Cake, maka konsumen semakin merasa puas terhadap produk King Cake. Sekelompok atribut penting dalam suatu produk akan mempengaruhi sikap puas/ ketidakpuasan konsumen terhadap produk atau jasa tertentu. Dengan adanya kualitas yang bagus dan terpercaya, produk akan senantiasa tertanam dibenak konsumen karena konsumen bersedia membayar sejumlah uang untuk membeli produk yang berkualitas (Kotler dan Armstrong dalam Saputra 2010:27). Tujuan akhir yang ingin dicapai oleh perusahaan adalah sama yaitu mampu memberikan rasa puas kepada konsumen. Puas atau tidak puasnya seorang konsumen ditentukan oleh kesesuaian antara harapan dengan persepsi konsumen pada kinerja aktual produk King Cake. Konsumen akan puas jika King Cake mampu memberikan kualitas produk yang sesuai harapan konsumen.

Hasil studi ini jugamembuktikan bahwa kajian teoritis dan studi empirik yang menyatakan dan adanya hubungan yang positif dan signifikan antara kualitas produk dan kepuasan nasabah juga dapat digunakan untuk studi dibidang makanan dan minuman di Indonesia khususnya pada King Cake di Surabaya. Hasil studi ini mendukung studi yang dilakukan Abdullah (2012), I. Jyoti Yadav (2011), dan Mohammad Ali serta Khaled (2011).

\section{Pengaruh Kualitas Layanan Terhadap Kepuasan Konsumen}

Kualitas layanan berpengaruh positif dan signifikan terhadap kepuasan konsumen. Hal ini berarti semakin baik kualitas layanan yang diberikan oleh King Cake, maka konsumen semakin merasa puas terhadap layanan King Cake. Kualitas layanan memiliki hubungan yang erat dengan kepuasan konsumen. Tercapainya kualitas layanan yang tinggi akan mendorong terciptanya kepuasan konsumen karena kualitas layanan merupakan sarana untuk mewujudkan kepuasan konsumen. Ketidakpuasan pada salah satu atau lebih dari dimensi layanan akan memberikan kontribusi terhadap tingkat layanan secara keseluruhan (Kotler, Fornell, dan Zeithaml dalam Sunyoto 2012:193-194).

Hasil studi ini juga membuktikan bahwa kajian teoritis dan studi empirik yang menyatakan adanya hubungan kausalitas yang positif dan signifikan antara kualitas layanan dan kepuasan konsumen dapat digunakan untuk studi dibidang makanan dan minuman di Indonesia khususnya pada King Cake. Hal ini sesuai dengan hasil studi yang telah dilakukan oleh peneliti sebelumnya yaitu Crinin dan Taylor (dalam Lovelock dan Wright 2007), Mohammad Ali (2011), dan juga Abdullah (2012).

\section{Keterbatasan Studi}

Hasil studi ini mempunyai keterbatasan untuk menjawab secara tuntas semua permasalahan yang terkait dengan hubungan antara variabel-variabel studi: kualitas produk, kualitas layanan, dan kepuasan konsumen.

1. Penelitian ini hanya mengambil 1 (satu) obyek penelitian yaitu industri UKM King Cake di Surabaya, tidak pada keseluruhan industri makanan dan minuman di Indonesia. Penelitian untuk seluruh wilayah Indonesia akan ditemui latar belakang sosial, ekonomi dan budaya yang berbeda sehingga kemungkinan akan terbentuk pola perilaku yang berbeda. 


\section{Monica Maria \\ Mohamad Yusak Anshori}

2. Penelitian ini mengggunakan analisis data berupa regresi linier berganda karena hanya ingin mengetahui pengaruh kualitas produk dan kualitas layanan terhadap kepuasan konsumen King Cake. Saran bagi penelitian selanjutnya diharapkan menggunakan importance-performance analysis agar perusahaan dapat mengetahui tingkat kepentingan kepuasan konsumen dan juga mengetahui kinerja perusahaan.

\section{KESIMPULAN}

Berdasarkan analisis studi dan pembahasan yang telah dilakukan, maka dapat disusun kesimpulan sebagai berikut:

1. Kualitas produk dan kualitas layanan berpengaruh positif terhadap kepuasan konsumen King Cake.

2. Kualitas produk berpengaruh positif terhadap kepuasan konsumen King Cake.

3. Kualitas layanan berpengaruh positif terhadap kepuasan konsumen King Cake.

\section{DAFTAR REFERENSI}

Abdullah, et al., 2012. The Influence of Service Quality and Price on Customer Satisfaction: An Empirical Study on Restaurant Services in Khulna Division. Journal Industrial Engineering Letters Vol. 2, No.2, p.25-33.

Anshori, Yusak dan Langner, Viviane. 2007. The Importance of Customer Satisfaction and Supreme Service Provision in The Hotel Industry: A Case Study of Surabaya Plaza Hotel. Jurnal Manajemen Perhotelan Vol. 3, No. 1, p.18-25.

Anwar, Y. 2010. Inspirasi Usaha Makanan Minuman untuk Home Industry. Jakarta: AgroMedia Pustaka.

BPS. 2010. Statistik Indonesia.

Irawan, Handi. 2009. 10 Prinsip Kepuasan Konsumen. Jakarta: PT. Elex Media Komputindo.

Keegan, Warren J.. 2007. Manajemen Pemasaran Global. Edisi Keenam. Jakarta: Indeks Kelompok Gramedia.

Kotler, Philip. 2010. Kotler on Marketing. Terjemahan: Kotler tentang Pemasaran. Tangerang: Karisma Publishing.

Kolter, Philip dan Armstrong, Gary. 2010. Principles of Marketing. Thirteenth Edition. New Jersey: Pearson Education.

Kotler, Philip dan Keller, Kevin Lane. 2009. Marketing Management. Thirteenth Edition. New Jersey: Pearson Education.

Kuncoro, Mudrajad. 2009. Metode Riset untuk Bisnis dan Ekonomi. Edisi Ketiga. Jakarta: Erlangga.

Lind, D.A., Marchal, W.G., dan Wathen, S.A. 2007. Teknik-Teknik Statistika dalam Bisnis dan Ekonomi. Buku Satu. Edisi Ketiga Belas. Jakarta: Salemba Empat.

Lind, D.A., Marchal, W.G., dan Wathen, S.A. 2008. Teknik-Teknik Statistika dalam Bisnis dan Ekonomi. Buku Dua. Edisi Ketiga Belas. Jakarta: Salemba Empat.

Lovelock, Christopher dan Wright, Lauren. 2007. Manajemen Pemasaran Jasa. Jakarta: PT. Indeks Kelompok Gramedia.

Majalah Service Excellent Edisi 02/ II. 2012. Perusahaan-Perusahaan yang Berhasil Membangun Service Excellent.

Mohammad Ali, Seyed Abbas, Khaled Nawaser \& Sayed Mohammad. 2011. A Case Study the Effects of Customer Service and Product Quality on Customer Satisfaction and Loyalty. Journal of Humanities and Social Science Vol. 1, No. 7, p.253-259.

Sarwono, Jonathan dan Martadiredja, Tutty. 2008. Riset Bisnis untuk Pengambilan Keputusan. Yogyakarta: Andi Offset.

Schiffman, Leon dan Kanuk, Leslie Lazar. 2008. Perilaku Konsumen. Edisi Ketujuh. Jakarta: PT. Indeks

Sugiyono. 2008. Statistik Nonparametris untuk Penelitian. Bandung: Alfabeta.

Sunyoto, Danang. 2009. Analisis Regresi dan Uji Hipotesis. Yogyakarta: Buku Tunggal. 
Sunyoto, Danang. 2012. Dasar-dasar Manajemen Pemasaran. Yogyakarta: Buku Seru. Tjiptono, Fandy. 2008. Strategi Pemasaran. Edisi Ketiga. Yogyakarta: Andi Offset. Umar, Husein. 2008. Metode Riset Bisnis. Jakarta: Gramedia Pustaka Utama.

Wibisono, Dermawan. 2011. Manajemen Kinerja Korporasi dan Organisasi. Jakarta: Erlangga. Yadav, I. Jyoti. 2011. Influence of Services and Product Quality towards Customer Satisfaction: A Case Study of Catherers, Sangli City. Research Paper Vol. 1, Issue. IX, p. 14. 